\title{
English Expressions and Terminologies Used for Reservation In PT. Raja Kamar Indonesia Jakarta
}

\author{
Sayyid Khairunas ${ }^{1}$ Fuji Versia ${ }^{2}$ \\ 1,2Sekolah Tinggi Ilmu Bahasa Asing Nusa Mandiri \\ Jl. Ir. Juanda No. 39 Ciputat, Tangerang \\ Email: ${ }^{1}$ sayyid.skh@bsi.ac.id, ${ }^{2}$ versiafuji@gmail.com
}

\begin{abstract}
The aim of this final paper is to describe the use of English expression and terms used in hotel room reservation activities. As for the background of writing this paper is related to the importance of the use of English expression properly in accordance with standard operating procedure in a company oriented to the theory from experts. The writer uses a description method that begins with research in PT. Raja Kamar Indonesia. From the analysis of the data from this study contains of conversation and descriptions of terminologies in travel agent. The conclusion of this paper is that readers can understand the work activities of a telephone operator in the hotel reservation division. The activity of expression in English that is used is asking inquiry, reservation, amendment, cancellation and refund. In addition, knowledge of the terms in the reservation becomes inseparable from the activity of reservation work. The author hopes this paper can help readers to know more deeply related to science in the field of reservation.
\end{abstract}

\section{Key Words: English Expressions, Terminologies, Reservation}

\section{INTRODUCTION}

English as foreign language in Indonesia is important as second language we need to understand. To speak English proficiency is lacking so many current course or a university place or academy that provides English majors to prepare the younger generation who are proficient in English. Not only learn in formal education, students may learn English in English Course or more practice with digital learning by using the internet.

English is very important in the field of tourism because English as International language used to communicate with people from all over the world before being able to speak other foreign languages. Many terms in the field of tourism that use English and have a meaning that can not be taken literally.

Currently Indonesia being aggressively to promote existing attractions to be known not only by domestic tourist but also foreigner tourists. Attractions explore more accompanied also by accommodation needed such as hotels, hostels, or homestay. Hence, the growing of hospitality industry followed by travel agents who sell accommodation with technology especially the local born online travel agent as we known today appeared in Indonesia.

The reason why the writer chose title "English Expessions and Terminologies Used For Reservation In PT. Raja Kamar Indonesia Jakarta” is the writer wants to discuss regarding English expressions in reservation division which has used daily by call center and customer service of the travel agent whether customers from foreign. Terminologies used in online travel agent also need to discuss the meaning of them. As for the terms are used in travel agent basically took from flight and hotel terms due to the travel agent sells flight ticket and hotel reservation.

Many things can be developed from the title of this paper due out by the writer's observation, online travel agent company have the basic procedure for language used in service to the customer but still have polite's grammar but straight to the point. Language used is what will be discussed further in this paper.

This paper can be used for reference of English expressions which it has dialogues used when communicate to the foreign customers can also be used as a reference formal language used in communication between the call center and customers. We are not only in theories but also have to know how to communicate correctly and politely based on the Standard Operating Procedures (SOP).

One of the aspects of the travel agent focused on call center communication are how to call center used English expressions, involves :

- How is the English expression when give suggestions

- How is the English expression when do the reservation

- Handling customers by phone 
- Handling customers when make cancellation and amendment

According to Background and reasons above, the writer sums up Some issues during research at PT. Raja Kamar Indonesia. The issues formulated in the following questions:

1. What English expressions are used in a hotel room reservation?

2. What are the activities in reservation?

3. What kind of terminologies used in reservation?

Currently Indonesia is very vigorous in promoting the tourism industry. Travel agents are one of the links of an integral part of the tourism industry itself. Through travel agents, potential travelers can get complete information about tourist destination information. The existence of travel agents can not only be found in travel offices, but currently many travel agents also provide online system experience which connected between travel agents and prospective travelers by using internet connection.

According to Boyd (1989:176) Travel agent makes travel arrangements and provides services directly to the public. They work with business (also referred as commercial), groups and individual pleasure traveler. Mostly, in one travel agent, customer service or Call Center is also available to handle all problems regarding certain issues.

Rangkuti (2013:3) stated: “Layanan call center adalah salah satu produk jasa layanan yang menjadi sisi terluar perusahaan. Karena layanan call center berinteraksi langsung dengan pelanggan sehingga baik atau buruknya suatu perusahaan dapat dinilai langsung oleh pengguna dari layanan call center. Sehingga banyak perusahaan berupaya untuk terus memperbaiki layanan call center mereka supaya dapat memenuhi kepuasan pengguna."

(Call center service is one of the service products that become the company's outermost. Because call center services interact directly with customers so that the good or bad of a company can be judged directly by the user of the call center service. So many companies are working to keep improving their call center services to meet user satisfaction).

Call center is a front line of a company which interact directly with customers. Call center is also an important division of a company due their responsibilities to handle any kind of suggestion, complain or after sales service comment which is intended for the company.
There are some expressions used which is quoted from Baehaqi (2011:9). Those will be divided into 5 parts. According to Oxford dictionary (2012:156) expressions is the things that people say, write or to show the feelings, opinions or ideas.

\section{A. Greeting}

Baehaqi (2011:9) conveyed: Greeting adalah salam atau tegur sapa yang digunakan untuk memulai sebuah percakapan. Greeting juga digunakan apabila kita menanyakan kabar seseorang atau sekedar basabasi untuk memulai percakapan. Sementara Partings adalah salam perpisahan yang digunakan untuk mengakhiri percakapan. (Greeting is used to start a conversation. Greeting is also used when we ask someone for news or just plain talk to start a conversation. While Partings is a farewell greeting used to end a conversation.)

Baehaqi also added, in expression for greeting commonly used is "Good morning", "Good afternoon”, "Good evening”. Also to ask about a person such as "How are you?", "How are you doing?”, "How you doing?", "What's happening?", "What's new?"

\section{B. Parting}

"In the expression for the parting, it could use a phrase commonly known as "preclosing" that will signal the end of a dialogue such as "I've really got to go now", "Got to go now", "I'm sorry, I must be going now", "I must be on my way". As for the "Closing" is used to end of the conversation such as "Talk to you later", "Until the next time", "See you later", "Good bye/bye", "Catch you later".

\section{Introduction}

Expression that can be used with the name as follows: "I’m John”, "Hello, I'm Jonathan Jenson", "Hello, my name is Lucky Andrian”, “I don't think we've met. I'm young Kim”, “Hi, I'm Mike. What's your name?”. Expression that can be use after introducing himself is "It is a pleasure to meet you", "Glad to meet you", "Pleased to meet you", "Nice to meet you". Introduction is basic in English expression which it open the conversation.

\section{Request and Suggestion}

In case of expression of request, there are some patterns that can be used, please + verb (more polite) such as "Please help me", "Can you help me?", "Would you help me?”, "Would you please help me?”. As for the expression used to ask others to repeat his words is "Excuse me?", "Could you repeat that?", "What did you say?", "Could you say that again?", "I'm sorry. I didn't catch that". 
According to the Merriam Webster dictionary suggestion is the process by which a physical or mental state is influenced by a thought or idea. The writer opinion according to theory above, suggestion is a psychic impulse about an idea. Asking suggestion means open with the idea source from others. The writer thinks that using polite and formal sentence when do the conversation while requesting and give suggestion in reservation is important due to call center staff as front line to build image of a company.

\section{E. Description}

Expression to describe something can also be used like- would like- look like- be like such as, "What kind of food do you like?”, "I like Chinese food”, "I like some food with spicy taste", "What kind of food would you like to starter?”, "I would like a shrimp avocado with thousand island".

From some of the theories above it can be concluded that English expression is things that people say, write or to do show their feelings, opinion or ideas which depends on the particular situation.

\section{F. Thanking}

Phrase commonly used to expressed thanks for instances : “I’m very greatful for...”, “I'm so greatful for...”, “Thank you very much for...”, “Thank you so much for...”, “Thanks a lot for...”, “Thank you for...”, “Thanks!”. According to Habeyb (2012:12) “Thanks the noun have a meaning and contains a more intimate than thank you".

Main activity in travel agent is reservation. Reservation is a main activity in RajaKamar. This reservation is done by calling the customer servce or call center by phone.

Suwithi (2008:101) said that "Reservasi adalah suatu proses permintaan pemesanan kamar dan fasilitas lain yang diinginkan oleh calon tamu untuk periode tertentu. Seluruh permintaan pemesanan kamar ini akan ditangani oleh petugas reservasi dengan mempertimbangkan keberadaan kamar pada saat itu. (Reservation is a process of requesting room reservations and other facilities desired by a prospective guest for a certain period. All requests for this room reservation will be handled by the staff taking into account the existence of the rooms at the time).

The writer thinks that reservation is a request from customer to the hotel to occupy any room or any facilities in the hotel. The process has certain date check in and check out. Hotel reservation mostly happens before due date of check in or in some cases customer may do the reservation in same day check in depend on their needs.
Some terminologies are used in reservation process at Rajakamar. According to Merriem-Webster dictionary, terminology is the technical or special terms used in a business, art, science, or special subject. The writer thinks that terminology used in specification subject to make it easier to understand. In other words, terminologies in travel agent are special words used in certain travel agent business. The words are commonly used in travel agent business to express a state with a compact language.

\section{RESEARCH METHODOLOGY}

The writer has done research in PT. Raja Kamar Indonesia to get more data and knowledge to compile this journal. The data are taken in Reservation division whose duty is handling customers who need assistance to reserve hotel and flight. The writer used descriptive qualitative method in composing this research in order to get systematic, factual, and accurate regarding the object of the reasearch. In the first stage, the writer collected data and materials required first, and on the next stage the writer cultivated and discussed up to the conclusion that ultimately can make a report to attach all activities done during research at Rajakamar.

Data collection is done in order to get information as well analyze the data so that the data can give an idea of object being researched. Primary data source is data or any information gained and obtained by the author directly from the first sources of the individual or a group of parts of the object research, such as interviews and direct observation on the object of the research. As for the interview implemented at Reservation division, covering frequent problems faced by Rajakamar especially in handling order and reservation of hotel and flight. The observations carried out in Rajakamar regarding problems that are often encountered by the company mainly about the reservations.

\section{RESULT AND DISCUSSION}

\subsection{The Structure of English Expressions Used in Dialogue}

Structure of English expression is important to get know good grammar in dialogue between call center / customer service with customer. More about English expression for reservation handle by customer service, and English expression of customer complaint dialogue.

English expression used in reservation is important to get to know by call center staff due to their job handling the customer. The selection of proper 
grammar is also a concern and SOP in call center division. In this section, will be discussed of English expression on some parts of customer handling commonly used when serving by phone as follows :

\subsection{Asking Inquiry}

Call center as a corporate image served as a liaison between the company and customer. It is important for the call center to give a good impression. Greetings is the first thing spoken by the call center. Greetings should be well done and polite in accordance with SOP. Here is an example of a "asking inquiry" conversation between Devi (Call Center) and Agnes (Customer).

Call Center : : "RajaKamar, Devi speaking how may I help you?”

Customer : : "Hi, I'd like to ask hotel near Kuta Beach area. Could you give me some suggestions?”

Call Center : " Yes, sure. What is your name, mam?”

Customer : : "My name is Agnes."

Call Center : : "Well, Mrs Agnes, there are Maria Hotel, Harris Hotel Kuta Beach, Best Western Kuta Beach, Discovery Kartika Plaza surronding Kuta Beach area. Which one do you prefer mam and when will you be stay at the hotel?”

Customer : :How much for the lowest rate in each hotels?"

Call Center : "May I know when will you check in and for how many night?"

Customer : "I will stay in 8th May for 3 nights."

Call Center : "Well, for Maria Hotel is IDR 250,000, Harris Hotel Kuta Beach IDR 650,000, Best Western Kuta Beach IDR 700,000, and Discovery Kartika Plaza IDR 1,200,000 per room per night including breakfast for 2 persons. Which one do you prefer mam?”

Customer : "Well, I will discuss with my family first then I'll call you later."

Call Center : : "Okay mam, please do not hesitate to contact us in this line. Thank you for calling Rajakamar and have a nice day.”
In conversation above, the writer found lack of greeting delivered by call center staff. This is not in accordance with the instructions in previous theories.

According to Baehaqi "In the expression for the greeting commonly used is "Good morning", "Good afternoon", "Good evening”. Also to ask about a person such as "How are you?", "How are you doing?”, "How you doing?", "What's happening?”, "What's new?".

\section{(Incorrect)}

Call Center : "RajaKamar, Devi speaking how may I help you?”

Customer : : "Hi, I'd like to ask hotel near Kuta Beach area. Could you give me some suggestions?”

(Correct)

Call Center : : “Good morning, RajaKamar, Devi speaking how may I help you?”

Customer : "Good morning, I'd like to ask hotel near Kuta Beach area. Could you give me some suggestions?”

\subsection{Reservation}

The main part of call center and customer activities is reservation. Usually, after giving suggestion, customer will consider to make reservation. In this case, it is important for the call center staff to give a good impression to the customer in this case is the language used must be polite in English. Here is an example of a "reservation" conversation between Devi (Call Center) and Agnes (Customer).

Call Center : "Good morning RajaKamar, Devi speaking how may I help you?”

Customer : : "Good morning. I want to reserve 1 room for 27 December 2017, 1 night.”

Call Center : : "Yes, sure, May I know your name mam?”

Customer : : "My name is Agnes.”

Call Center : : "Well Miss Agnes, you will be stay at the hotel or you reserve for other?"

Customer : : "I will book for my family."

Call Center : "Miss Agnes, what hotel do you want to reserve?”

Customer : : "Hard Rock Hotel Bali, please.” 
Call Center : :Hard Rock Hotel Bali for Deluxe room is IDR 1,500,000 per room per night inclusive breakfast for two persons."

Customer : “ Okay please reserve it.”
Call Center : "May I know your phone number
and do you have any special request, Miss?”
Customer : "My phone number is 08387284
5066 and I want double room.”
Call Center : "What is your email address, Miss
Agnes?”
$\begin{aligned} & \text { Customer : "My email address is } \\ & \text { agnes@gmail.com.” }\end{aligned}$

Call Center : : "Do you have any special request, mam?”

Customer : : :Yes, I want connecting room."

Call Center : :I will repeat the reservation. You reserved Hard Rock Hotel Bali from 27-28 December 20172 Deluxe room connecting room inclusive breakfast with customer's name is Miss Agnes, your phone number is 083872845066 your request is double room, and your email address is agnes@gmail.com. Is it correct Miss?”

Customer : :Yes."

Call Center : "Well Miss Agnes, your reservation is confirmed, I will send you an sms detail of your reservation and our bank account to transfer, Please do the bank transfer not more than 1 hour or your reservation will be release.”

Customer : : “Thank you.”

Call Center : : "Okay mam, please do not hesitate to contact us in this line. Thank you for calling Rajakamar, have a nice day.”

In conversation above, found a structure suitable based on the theory in the previous chapter. Here is the explanation regarding theory of description in English expression.

According to Baehaqi expression to describe something an also be used like- would like- look likebe like such as, "What kind of food do you like?", "I like Chinese food", "I like some food with spicy taste", "What kind of food would you like to starter?", "I would like a shrimp avocado with thousand island"

\section{(Incorrect)}

Call Center: "Miss Agnes, what hotel do you want to reserve?”

Customer: "Hard Rock Hotel Bali."

\section{(Correct)}

Call Center: "Miss Agnes, what kind of hotel do you want to reserve?"

Customer : "Hard Rock Hotel Bali, please.”

\subsection{Amendment}

Amendment occurs when the customer has made a reservation and paid the booked room before but want to make changes to hotel orders, check in / out date, and number of rooms. Here is an example of "amendment" conversation between Devi (Call Center) and Agnes (Customer).

Call Center : "Good Morning RajaKamar, Devi speaking how may I help you?”

Customer : : "I'd like to do amendment, change date my reservation before."

Call Center : : "Sure, for when ?"

Customer : "I would like to stay from 2 to 6 instead of 3 to 7 of December 2017.”

Call Center : "May I know your name, mam?”

Customer : : "My name is Agnes.”

Call Center : : "Well Miss Agnes, may I know the reservation number?"

Customer : : Yes, RKB 130055.”

Call Center : "Well, RKB 130055 with guest name Agnes Monica for Hard Rock Hotel Bali, 1 Deluxe Room want to change check in date from 2 to 6 instead of 3 to 7 of December 2017. Is it correct, mam?”

Customer : : " Y Yes, correct.”

Call Center : "Wait a minute mam, I'd like to check the availability first... (checking the room). Thank you for patient mam, 1 Deluxe room is available on 2 until 6 December 2017. May I process it now?”

Customer : : :Yes, sure."

Call Center : :Well Miss Agnes, the amendment is confirmed and the voucher will be sent to your email. Anything else, mam?” 
Customer : : "Perfect, thank you for your help." Call Center : "Okay mam, please do not hesitate to contact us in this line. Thank you for calling Rajakamar, have a nice day.”

In conversation above, the writer found unsuitable part with the theory in previous chapter. The detail will explain as below:

According to Baehaqi expression that can be used to express suggestions or offer something is "I think you should...", "I don't think you should", "Why don't you...", "Here. Have a coke", "How about a glass of wine?”. "Would you like some more coke?”.

\section{(Incorrect)}

Customer: "I'd like to change date my reservation before."

Call Center: "Sure, for when?”

\section{(Correct)}

Customer: "I'd like to change date my reservation before."

Call Center: "Sure, when do you want to stay?"

\subsection{Cancellation and Refund}

Cancellation commonly happens in reservation. This is because of various things such as, customers in a state of urgency, sickness, the condition of the hotel is out of estimates such as riots, or anything else that resulted in customers can not come to the hotel on a date that has been reserved. The cancellation rate is not usually about $2 \%$ of the total confirmed reservation. After cancellation, the customer's money automatically entered into the travel agent must be returned in accordance with the agreement between the guest and the travel agent. This is usually called refund. In this section we will discuss about the intermediate conversation "Cancel and Refund" between Devi (Call Center) and Agnes (Customer).

Call Center : "Good Morning RajaKamar, Devi speaking how may I help you?”

Customer : "I want to cancel my reservation because I have to do Something."

Call Center : : "May I know your name, mam?”

Customer : :My name is Agnes.”

Call Center : : "Well Miss Agnes, may I know the reservation number?”
Customer : : "Yes, RKB 130066.”

Call Center : "Well, RKB 130066 with guest name Agnes Monica for

Neo Hotel Bali, 1 Superior Room want to cancel check in date from 20 to 23 December 2017. Is it correct, mam?"

Customer : : :Yes and can I have money back?”

Call Center : "Yes, mam we will do the refund for your reservation. May I have you Bank account to transfer it?”

Customer : "BCA Johar Baru branch Jakarta 22331332 under name Agnes Soraya.”

Call Center : "Well, thank you for your information mam. Total refund amount is IDR 1,500,000 and it will be process and transfer to you account maksimum 14 working days. Do you need anything else, mam?”

Customer: "No, thanks anyway."

Call Center: “Alright.”

In conversation above is almost based on the structure of English expression but there is a lackness in there. According to Baehaqi, phrase is commonly used to express thanks in a polite manner for instances: "I'm very greatful for...”, "I’m so greatful for...”, "Thank you very much for...”, "Thank you so much for...”, “Thanks a lot for...”, “Thank you for...”, “Thanks!”.

According to Habeyb (2012:12) "Thanks is the noun which has a meaning and contains a more intimate than thank you."

(Incorrect)

Customer: "No, thanks anyway."

Call Center: "Alright.”

\section{(Correct)}

Customer: "No, thanks anyway."

Call Center: "Thank you for calling Rajakamar, have a good day."

\subsection{Terminologies in Reservation and Caused}

Many terms used in travel agents, especially hotel divisions, some of them are difficult to understand their meaning. Therefore, in this chapter, the writer will discuss further about the meaning and caused of terminologies used for reservation in hotel division. The terminologies as basic knowledge of call center in travel agent hotel division.

1. Confirmed 
Is a condition where the reservation has been approved by hotel and customer may check in based on their arrival date. When the reservation is confirmed, reservation staff may have a payment from the guest and staff give a hotel voucher used when guest check in.

2. Cancel

Is a condition where customer want to cancel the reservation due to one or other reasons customer can not check in at the hotel. Usually if the cancellation occurs several days near the arrival date or the arrival date is high/ peak season, then the hotel charged a cancellation fee.

\section{Amendment}

The condition occurs when customer want to change their reservation has been confirmed and paid. The amendment usually in arrival or departure date, length of stay, and room type (upgrade or downgrade). Travel agent usually has their regulation to charged the customer amendment fee (around IDR 50,000/ invoice).

\section{Refund}

Occurs due to the customer who canceled the reservation but has paid the fee, then the money paid will be refunded.

5. Connecting Room

Is a condition where is 2 rooms located side by side has connecting door. It usually consists of 1 double bed and 1 twin bed and suitable for family with two children for their convenience. Hotel has not many connecting room and only a few in each floor.

6. Special Request

A request from customer to hotel where he/she would like to stay out of standard facility in hotel such as connecting room (if reserve 2 rooms), pool view, near the lift, non smooking room, high floor and so on.

7. High Season

A period when the center of recreation, tourism and leisure experienced an increase in the number of visitors. This is due to long holidays for workers and students. High season usually takes place on Lebaran, Christmas, New Year, school holidays and long weekend. Characterized by an increase in ticket prices for tours and accommodation.

\section{Low Season}

A period when decrease in visits to the recreation center. Low season usually occurs in Ramadan, rainy season (October to April), and weekday (Monday to Thursday). Low season is also marked by the decrease in tour ticket prices and accommodation rate. In this period, the hotel occupancy rate was also low. Usually the hotel can provide free room type upgrade or check in earlier.

9. Surcharge
Is an additional cost paid by the customer. Surcharge is usually charged in high season period where is high demand and limited supply.

10. Extend Night

It is an additional night or extend request by customer. 11. Black Out Date

The date which close out for reservation. Usually due to the arrival of the hotel entourage of the lodge so that the room inventory is depleted or exhausted.

12. Adjoining Room

Different from connecting room, adjoining room is 2 rooms located side by side but there is no connecting door inside the room. Adjoining room usually request by a group booking.

13. Extra Bed

Additional bed that used if guest is over capacity in a room.

14. R.O.H (Run of House)

Is free room type which guest will know the room type when they have arrived at the hotel. In other meaning, Run of House is room type that available upon guest check in.

15. Fully Booked

Is the condition where is the room is full at the hotel and reservation can not be made. It happens due to high demand in high season period.

16. Allotment

Is amount of room allocate in a hotel. Beside of room rate, room allotment is important in reservation process.

17. Twin Bed

Room with 2 single beds and size is $120 \times 120 \mathrm{~cm}$ each.

18. Double Bed

Room with one bed and size is $180 \mathrm{x} 200 \mathrm{~cm}$ or $200 \mathrm{x}$ $200 \mathrm{~cm}$.

\section{CONCLUSION}

English expression used in hotel reservations has been discussed previously, those consist of; greeting, parting, introduction, request and suggestion, description and thanking. Polite language is also important to use because it is official in serving customers. As call center staff, they have to know every steps of English expressions due to their responsibilities as front liner in a company.

English expressions used for activities in PT. Raja Kamar Indonesia divided into several situations; asking inquiry, reservation (when customer wants to book), amendment arrival or departure date, cancellation and refund. All situations are done by reservation staff in a daily basis. Differences in situations encountered, then different handling and use of English expression. Therefore, in this final paper, the writer describe the full range of dialogues 
commonly used by reserve staff in handling customers.

The terminologies are commonly used from staff to customer or internal (staff to staff). Some terminologies can not be explained in literary, then staff must know about terminologies used for reservation such as confirrmation, cancelation, refund, amendment, bedding type or reservation season and many other terminologies that is used in daily reservation activities.

\section{BIBLIOGRAPHY}

Anugerah, Andi. 2009. Sukses Mengelola Call Center Manajemen Kinerja. Jakarta: Telexindo Bizmedia.

Atmadjati, Arista. 2012. Era Maskapai Saat Ini Website Base. Yogyakarta: LeutikaPrio.

Baehaqi, Imam . 2011. Essential Expressions In English Conversation. Tegal: Media Ilmu.

Darsono, Agustinus. 2011. Front Office Hotel. Jakarta : Grasindo.

Heny, Grace. 2012. CALL CENTER HANDBOOK: Mengupas Tuntas Layanan Pelanggan. Jakarta: Elex Media Komputindo.

Kasavana, Michael L. and Brooks Richard M. 2012. Managing Front Office Operations 8th Edition. USA: Educational Institute.
Rangkuti, Freddy. 2013. Customer Service Satiscaction \& Call Centre Berdasarkan ISO 9001. Jakarta: Gramedia Pustaka Utama.

Suwithi, Ni Wayan dkk. 2008. Akomodasi Perhotel Jilid 110 SMK. Jakarta: Pusat Perbukuan Departemen Pendidikan Nasional.

https://www.merriam-

webster.com/dictionary/travel\%20agency (accessed 17 May 2017).

https://www.merriam-

webster.com/dictionary/terminology (accessed 24 May 2017).

\section{PROFILE}

Sayyid Khairunas, S.S, M.Pd. was born in Jakarta, 15 October 1989. The second child of three is a graduate of STIBA Nusa Mandri Jakarta in 2013 and graduated from Universitas Indraprasta PGRI Jakarta in 2016 majoring in Teaching English and Education. Join BSI since 2012, in the midst of busy life, he still took time to write articles, ideas, experiences, journeys, and views via his personal blog. 